\title{
Microbial populations in wetwood of European white fir ( Abies alba Mill.)
}

(Quantification of microbial populations; wetwood; European fir dieback; forest decline; Protaminobacter; Pseudomonas; yeasts)

\section{Marlies Streichan * and Bernhard Schink}

Fakultät für Biologie, Universität Konstanz, Postfach 5560, D-7750 Konstanz, F.R.G.

Received 19 March 1986

Accepted 26 March 1986

\section{SUMMARY}

A method for extraction of microbial populations from wood samples was worked out which gave good recovery of both aerobic and anaerobic microorganisms in agar shake dilution and plating enumerations. This method was applied to the quantification of microbial populations in three European white firs ( $A$ bies alba Mill.) which were afflicted with the European fir disease. Low numbers of aerobic microorganisms $\left(10^{2}-10^{4}\right.$ colonyforming units (cfu) per $\mathrm{g}$ fresh tissue) were detected in sapwood irrespective of the degree of affliction. Anaerobic bacteria were usually 1-2 orders of magnitude less frequent. Wetwood of highly diseased firs contained significantly higher numbers of aerobic microorganisms $\left(10^{5}-10^{7}\right)$, whereas the number of anaerobes was not enhanced significantly. Among the prevalent aerobic microorganisms in wetwood were Protaminobacter, Pseudomonas strains, and a yeast. In anaerobic counts from wetwood, Klebsiella and

\footnotetext{
* To whom correspondence should be addressed, at present address: Institut für Mikrobiologie, Universität Freiburg, Schänzlestrasse 1, D-7800 Freiburg, F.R.G.
}

Vibrio strains predominated. The sapwood contained Bacillus, Beijerinckia, Staphylococcus, and Clostridium spp. High numbers of aerobic microorganisms were also detected in the roots and lower stem of a diseased vine plant (Vitis vinifera L.). The importance of microbial populations in wetwood formation and disease expression is discussed.

\section{INTRODUCTION}

Wetwood is an atypical condition of the heartwood of many living trees including both gymnosperms and angiosperms [1,2]. It differs from normal heartwood usually in its higher water content and darker tissue colour, often associated with a fetid smell of fatty acids. Depending on the tree species concerned, various types of wetwoods are expressed. Elms, cottonwoods, and poplars have completely anaerobic wetwood zones of slightly alkaline $\mathrm{pH}$ in the stem, in which some wood constituents are more or less completely converted to methane, carbon dioxide, and small amounts of fatty acids [3-8]. In firs, red oak, sugar pine, and Western hemlock, anaerobic acidic wetwood develops, which is characterized by ac- 
cumulation of fatty acids and $\mathrm{pH}$ decline to 3.3-5.7 [1,8-10]. Wetwood of other tree species appears to be microaerobic to aerobic, but reliable studies are scarce [9,11-13].

The alarming forest decline in Central and Western Europe, especially the fir dieback in Germany and Czechoslovakia in the last 10 years, has brought the wetwood problem back into discussion. Diseased white fir (Abies alba Mill.) always exhibits extended wetwood formation in the center of the stem, often spreading out into the sapwood [14-16]. Fatty acids (acetate, propionate, butyrate) accumulate, and the $\mathrm{pH}$ drops to 4.2-5.2. From these findings, wetwood of the European white fir should be characterized as belonging to the acidic anaerobic type. Bacteria isolated from fir wetwood were assigned to the genera Corynebacterium, Staphylococcus, Erwinia, Clostridium, and Lactobacillus [16]. However, these strains were isolated randomly from wood samples, and no effort was made to estimate population sizes of the various groups of bacteria or to define predominant groups.

The present study was initiated to develop a method for optimal recovery of aerobic and anaerobic bacteria from wood samples. The method had to be simple and able to be used for reliable recovery of aerobic and anaerobic bacteria, even in laboratories not equipped with anaerobic hoods, etc., for the cultivation of fastidious anaerobes. An appropriate standard method was then applied to the characterization of microbial populations in sapwood and wetwood of firs at various stages of disease.

\section{MATERIALS AND METHODS}

\subsection{Organisms}

Pure cultures of the following bacteria were used for extraction and cultivation experiments: Clostridium pasteurianum DSM525; Desulfovibrio vulgaris strain Marburg, DSM2119; Pelobacter propionicus DSM2379; Pseudomonas fluorescens, a new isolate from Lake Constance water.

\subsection{Sampling material}

For preliminary extraction and enumeration studies, activated sludge and anaerobic sewage digestor sludge from the municipal sewage plant in Konstanz, F.R.G., was used.

Wood samples were taken from three white firs (Abies alba Mill.) all grown within the forestry area of Bad Herrenalb, Black Forest, F.R.G. at an elevation of $400-450 \mathrm{~m}$. The trees were about 100 years old and $22-26 \mathrm{~m}$ tall. Slices of the stem were taken for sampling at $0.5 \mathrm{~m}, 8.5 \mathrm{~m}$, and $15 \mathrm{~m}$ height of the respective trees.

For comparison, wood of a diseased vine plant (Vitis vinifera L.) grown at the Batzenberg, Markgräflerland, F.R.G., was also studied.

All wood samples were used within 1-3 days of sampling, and were stored at $4^{\circ} \mathrm{C}$ before processing.

\subsection{Preparation of wood extracts}

Wood cores of $4 \mathrm{~mm}$ diameter and $30-70 \mathrm{~mm}$ long were taken with an increment core borer (Forstkultur, Frankfurt, F.R.G.) which was surface-sterilized with $70 \%$ ethanol and rinsed with sterile distilled water. Before coring, the surface of the wood sample was smoothed and cleaned with a flame-sterilized chisel. Cores were transferred into sterile anaerobic tubes which were gassed with $\mathrm{N}_{2} / \mathrm{CO}_{2}$ gas mixture ( $80 \%: 20 \%$ ), and closed with black rubber bungs.

For extraction of bacteria, cores or sludge samples were transferred into $50 \mathrm{ml}$ of an appropriate buffer solution (see below) in a small Waring blender beaker which was immersed in a large glass cylinder gassed with $100 \% \mathrm{CO}_{2}$. Samples were blended for $2-5 \mathrm{~min}$ at 30 -s intervals to avoid overheating. The extract was transferred immediately into gassed anaerobic tubes and subjected to counting procedures in the same manner as cell suspensions of pure cultures. The extraction buffers used were based on potassium phosphate, $\mathrm{pH} 7.0$, at 5, 10 and $50 \mathrm{mM}$ concentration; $50 \mathrm{mM}$ sodium citrate, $\mathrm{pH}$ 5.1; Tris- $\mathrm{HCl}, \mathrm{pH} \mathrm{7.5,} \mathrm{at} 5$ and $50 \mathrm{mM}$ concentration; Tris- $\mathrm{HCl}, \mathrm{pH} 8.5,50 \mathrm{mM}$. All buffers were kept $\mathrm{O}_{2}$-free by degassing and storage under $\mathrm{N}_{2}$ gas. Reducing agents (sodium sulfide, sodium ascorbate, cysteine- $\mathbf{H C l}$, sodium thioglycollate, dithioerythritol) were added from anoxic stock solutions to final concentrations of 1.0-3.0 mM. To improve the resolution of ad- 
sorbed bacteria from wood particles, the following agents were added from stock solutions to the respective final concentrations: ethylenediamine tetraacetate, $2 \mathrm{mM}$; nitrilotriacetate, $2 \mathrm{mM}$; Triton $\mathrm{X}-100,0.2 \mathrm{~g} \cdot 1^{-1}$; sodium deoxycholate, 0.3 $\mathrm{g} \cdot \mathrm{1}^{-1}$; Tween-80, $1.0 \mathrm{mg} \cdot \mathrm{1}^{-1}$; cetyltrimethylammoniumbromide, $0.2 \mathrm{mg} \cdot 1^{-1}$; sodium pyrophosphate, $3.0 \mathrm{~g} \cdot 1^{-1}$; urea, $100 \mathrm{mM}$; glycine, $100 \mathrm{mM}$. In some cases, a sonifier (Bransonic 220) was used to improve resolution.

\subsection{Media, cultivation, and enumeration}

For cultivation of anaerobic bacteria, a mineral medium was used which contained sodium bicarbonate as buffer and sodium sulfide as reducing agent [17,18]. Aerobic bacteria were grown in a mineral medium containing per $1: 0.3 \mathrm{~g} \mathrm{KH}_{2} \mathrm{PO}_{4}$; $2.1 \mathrm{~g} \mathrm{Na} \mathrm{NPO}_{4} \cdot 2 \mathrm{H}_{2} \mathrm{O} ; 0.5 \mathrm{~g} \mathrm{NH} \mathrm{NH}_{4} \mathrm{Cl} ; 0.2 \mathrm{~g}$ $\mathrm{MgCl}_{2} \cdot 6 \mathrm{H}_{2} \mathrm{O} ; 0.05 \mathrm{~g} \mathrm{CaSO}_{4} ; \mathrm{pH}$ 7.0. Solid aerobic media contained $1.2 \%(\mathrm{w} / \mathrm{v})$ agar. All media received $1.0 \mathrm{ml}$ trace element solution $\mathrm{SL}$ 10 per 1 [19].

Organic substrates were added from separately autoclaved or filter-sterilized stock solutions. Insoluble substrates (cellulose, hemicelluloses) were autoclaved as dry powder in test tubes which received the sterile medium afterwards. $C$. pasteurianum was grown with $2 \mathrm{mM}$ glucose, $D$. vulgaris with $10 \mathrm{mM}$ lactate and $10 \mathrm{mM}$ sulfate, $P$. propionicus with $10 \mathrm{mM}$ 2.3-butanediol, and Ps. fluorescens with $10 \mathrm{mM} \mathrm{L}$-tartrate. The standard media for enumeration of bacteria in wood samples contained a mixture of cellobiose, xylose, lactate, and yeast extract, each $0.50 \mathrm{~g} \cdot 1^{-1}$.

Anaerobic bacteria were enumerated by counting colonies in agar shake dilution series [20] prepared in $1: 10$ dilution steps in 2 parallel series each. Aerobic bacteria were enumerated in a similar manner by dilution in agar-containing growth medium which was poured into Petri dishes. Tubes and plates were incubated at $28^{\circ} \mathrm{C}$ for $2-3$ weeks before evaluation.

\subsection{Isolation of pure cultures}

Pure cultures of numerically prevalent bacteria were isolated from the last positive dilution tubes using Pasteur capillary pipettes [20], suspended in a small amount of the same medium, and diluted again in agar shake series or agar plate cultures, or streaked on agar plates. Colonies were transferred into liquid medium and checked for purity by microscopic observation, also after growth in complex medium (AC-medium, Difco, Detroit, MI U.S.A.).

\subsection{Characterization of isolates}

Gram staining was carried out according to [21]. Aerobic and anaerobic growth, and acid and alkali formation, were checked according to [22]. Tests for oxidase, catalase, urease etc., as well as growth tests on special substrates were done with commercial identification systems (API - 20 A and 20 E; Bio Merieux, Nürtingen, F.R.G.).

Fermentation products (alcohols, fatty acids) were identified by gas chromatography [18]. Hydrogen was trapped in Durham tubes in liquid cultures, or identified by gas chromatography using a Carlo Erba gas chromatograph with a molecular sieve column ( $5 \AA$ ) and a thermal conductivity detector.

\subsection{Chemicals}

All chemicals used were of analytical grade quality and obtained from Merck, Darmstadt, F.R.G., Riedel-de-Haen, Hannover, F.R.G. and Fluka, Buchs, Switzerland, who also provided xylan. Arabinogalactan was purchased from Janssen, Beerse, Belgium; complex medium additions (agar, yeast extract) were from Difco.

\section{RESULTS}

\subsection{Optimization of extraction and counting meth- ods}

The first goal of the present study was to develop a suitable procedure for the extraction and enumeration of aerobic and anaerobic bacteria in wood samples. The latter usually require the presence of reducing agents, which may be toxic to the former.

Washed suspensions of Ps. fluorescens, P. propionicus, $C$. pasteurianum, and D. vulgaris as representatives of strict aerobes, anaerobic fermenters, and sulfate-reducers, respectively, were shaken with or without a variety of reducing agents 
under air for $60 \mathrm{~min}$, and the number of surviving cells was determined by serial dilution as described. The results were consistent in 2 parallel experiments, and can be summarized as follows (Table 1): Pseudomonas and Desulfovibrio survived well in the absence of any reducing agent, whereas Pelobacter survived only partially, and Clostridium was killed almost completely. Ascorbate allowed sufficient survival (30-94\%) of all 4 strains tested, whereas agents containing sulfhydryl groups (thioglycollate, dithioerythritol, cysteine) killed high percentages, particularly of the fermenting bacteria. From these experiments it was concluded that ascorbate gave sufficient protection to strict anaerobes in the presence of traces of air without marked killing of aerobic bacteria.

Similar results were obtained when a potassium phosphate-buffered wood extract was treated as the cell suspensions above: the highest numbers of anaerobic bacteria were recovered from ascorbatereduced suspensions, whereas extracts without a reducing agent or with cysteine, thioglycollate or dithioerythritol yielded $30-40 \%$ less surviving anaerobes.

The influence of the $\mathrm{pH}$ of the extraction buffer on the recovery of bacteria was studied with potassium phosphate buffer at $\mathrm{pH} 7.0$, citrate buffer at $\mathrm{pH}$ 5.1, and Tris- $\mathrm{HCl}$ buffer, $\mathrm{pH} 7.5$ and 8.5. The highest numbers were obtained with potassium phosphate buffer at $\mathrm{pH} 7.0$, while at pH 7.5 and 5.1 only about $30 \%$ of these numbers could be recovered, and only $10 \%$ at $\mathrm{pH} 8.5$. The buffer strength was optimal at $5 \mathrm{mM}$ concentra- tion; at 10 and $50 \mathrm{mM}$ potassium phosphate concentration, the colony counts decreased by about $30 \%$.

Addition of complexing agents (ethylenediamine tetraacetate, nitrilotriacetate), tensides (cetyltrimethylammonium bromide, Triton X-100, Tween 80 , sodium deoxycholate), or other compounds (glycine, urea, sodium pyrophosphate) did not improve the recovery of living bacteria, either when added to anoxic sewage sludge or when applied to wood samples. On the contrary, numbers of surviving bacteria decreased by $80-98 \%$ if these compounds were added to the extraction buffer.

Sonication, treatment with a teflon-potter, or repeated evacuating and gassing of wood homogenates did not increase the numbers of living bacteria, either. Prolonged sonication (10 min at $20 \mathrm{kHz}$ ) killed $50-70 \%$ of the bacterial population.

Based on all these experiments, an oxygen-free $5 \mathrm{mM}$ potassium phosphate buffer, $\mathrm{pH} 7.0$, with 2 $\mathrm{mM}$ sodium ascorbate as reducing agent, was used as standard extraction buffer for all further enumeration experiments. Wood core samples were homogenized in this buffer in a Waring blender under a carbon dioxide atmosphere to avoid excessive contact with air.

For enumeration and cultivation of bacteria from wood samples, two mineral media were used, a carbonate-buffered one for anaerobes and a phosphate-buffered one for aerobes. A mixture of cellobiose, xylose, lactate, and yeast extract was added at low concentration $\left(0.5 \mathrm{~g} \cdot 1^{-1}\right.$ each $)$ to

Table 1

Influence of reducing agents on survival of pure bacterial cultures under air

Cell suspensions contained $10^{8}-10^{9}$ cells $\cdot \mathrm{ml}^{-1}$ in $20 \mathrm{mM}$ potassium phosphate buffer, $\mathrm{pH} 7.0$. The numbers are means of 2 independent experiments and give percentages of surviving cells compared to untreated suspensions. Reducing agents were added at $3 \mathrm{mM}$ concentration.

\begin{tabular}{|c|c|c|c|c|}
\hline $\begin{array}{l}\text { Reducing } \\
\text { agent }\end{array}$ & Ps. fluorescens & P. propionicus & C. pasteurianum & D. vulgaris \\
\hline None & 100 & 56 & 1 & 97 \\
\hline Na-Ascorbate & 73 & 59 & 29 & 94 \\
\hline Na-Thioglycollate & 52 & 1 & 4 & 10 \\
\hline Dithioerythritol & 70 & 1 & 2 & 70 \\
\hline Cysteine-HCl & 19 & 66 & 44 & 72 \\
\hline
\end{tabular}


mimic the comparably poor nutrient supply in wood. Highest numbers of aerobic and anaerobic bacteria were obtained at $\mathrm{pH}$ 6.0-7.0. A combination of $2 \mathrm{mM}$ sodium ascorbate and $0.2 \mathrm{mM}$ cysteine proved to be optimal as reducing agent and sulfur source; with sulfide, less than $10 \%$ recovery was obtained.

The following results were obtained with this standard procedure for extraction and cultivation.

\subsection{Enumeration of microbial populations in wetwood of fir}

Three European white firs (Abies alba Mill.), Nos. 107, 118, and 119, were sampled for enumeration experiments. Trees Nos. 107 and 118 both exhibited the typical symptoms of 'European white fir dieback'. The crowns were transparent due to high needle loss; only the needles of the last 2-3 yr remained, and had in part turned yellow to brownish (damage class 3 ). After cutting, wetwood formation in the center of the stem was observed, reaching from the base up to more than $8.5 \mathrm{~m}$ height. Tree No. 119 was in better condition (damage class 2), but also had wetwood in the base region. Wetwood was in all cases slightly darker than the surrounding heartwood, and extended from the center to about half of the stem diameter (Fig. 1). The borderline between heartwood and wetwood was marked by a thin $(0.5-2.0 \mathrm{~mm}$ wide) dry zone and one or more irregular dark lines reaching inwards resulting from precipitated phenolic wood extractives. All wetwoods produced a slightly fetid smell of butyric acid.

Populations of aerobic and anaerobic bacteria were enumerated using the standard procedure described above (Table 2). The comparatively healthy tree No. 119 contained aerobic and anaerobic bacteria in low numbers $\left(\leqslant 10^{4}\right)$ in sapwood and wetwood above $8.5 \mathrm{~m}$ high. At $15 \mathrm{~m}$ high, there was no more wetwood present, and both sapwood and heartwood were almost devoid of bacteria. In the severely afflicted trees Nos. 107 and 118, the numbers of aerobic and anaerobic bacteria found in the sapwood were about the same as in tree No. 119. In the wetwood, however, the numbers of aerobic bacteria increased dramatically from the periphery to the center,

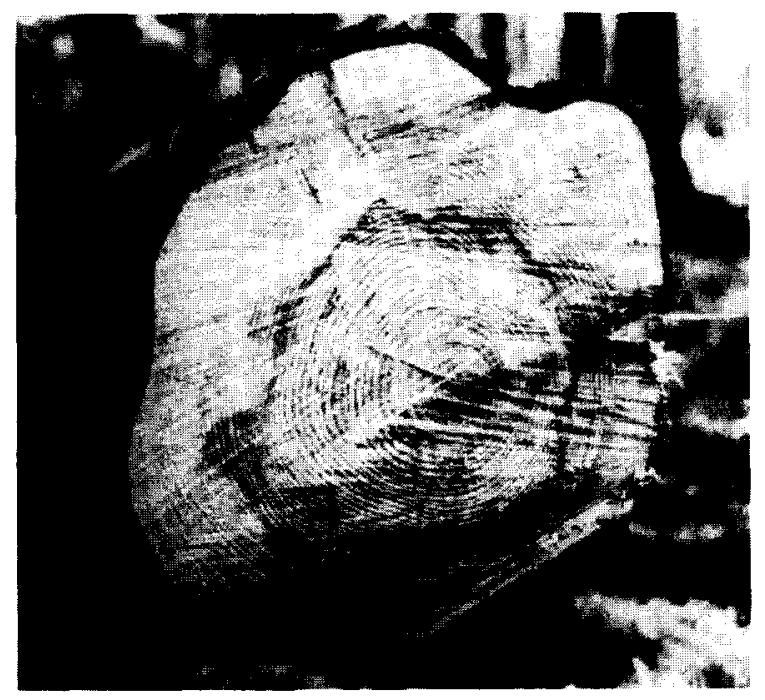

Fig. 1. Cut surface of tree No. 118 showing irregular spreading of wetwood from the center to the sapwood.

whereas the number of anaerobes remained low. Anaerobes were numerically of only minor importance in these trees.

\subsection{Characterization of prevalent microorganisms from fir wood samples}

Prevalent microorganisms were picked from the last positive dilution tubes in each dilution series, and rediluted in the same medium for purification. The strains isolated from these colonies can therefore be considered significant constituents of the microbial populations of the wood samples. 34 strains were isolated and characterized by physiological and biochemical criteria. They were grouped into 10 pools of physiologically similar strains and assigned to genera. Representatives of each pool are presented in Table 3.

Among the predominant microorganisms in wetwood samples was a yeast which occurred in both wetwood and heartwood of trees No. 118 and 119. It was not further characterized.

Strain Taae11 represents several isolates from wetwood as well as heartwood and sapwood samples. Its assignment to the genus Protaminobacter (probably Protaminobacter ruber) could be corroborated by demonstrating the presence of bacteriochlorophyll [23]. Two further types of 
Table 2

Numbers of aerobic and anaerobic bacteria in wood samples of three white firs (Abies alba Mill.)

All numbers give means of two independent dilution experiments starting with the same wood extract. The standard deviation was calculated as the square root of sample variance, and was 0.72 in all cases. Numbers are related to the mass of fresh wood samples. The water content of the samples was determined gravimetrically before and after drying and varied between 50 and $70 \%$.

\begin{tabular}{|c|c|c|c|c|}
\hline \multirow[t]{2}{*}{ Tree No. } & \multirow{2}{*}{$\begin{array}{l}\text { Sampling } \\
\text { height }\end{array}$} & \multirow{2}{*}{$\begin{array}{l}\text { Tissue } \\
\text { sampled }\end{array}$} & \multicolumn{2}{|c|}{ Number of bacteria per $\mathrm{g}$ fresh wt. } \\
\hline & & & Aerobic & Anaerobic \\
\hline 119 & $\begin{array}{r}8.5 \mathrm{~m} \\
15.0 \mathrm{~m}\end{array}$ & $\begin{array}{l}\text { Sapwood } \\
\text { Wetwood edge } \\
\text { Central wetwood } \\
\text { Sapwood } \\
\text { Wetwood edge } \\
\text { Central wetwood } \\
\text { Sapwood } \\
\text { Heartwood }\end{array}$ & $\begin{array}{r}4.7 \times 10^{4} \\
1.4 \times 10^{2} \\
1.7 \times 10^{3} \\
2.8 \times 10^{4} \\
7.0 \times 10^{3} \\
7.7 \times 10^{3} \\
<10^{2} \\
2.2 \times 10^{2}\end{array}$ & $\begin{array}{r}1.2 \times 10^{3} \\
1.1 \times 10^{3} \\
1.9 \times 10^{4} \\
1.3 \times 10^{4} \\
<10^{2} \\
1.1 \times 10^{2} \\
<10^{2} \\
1.1 \times 10^{2}\end{array}$ \\
\hline 107 & $0.5 \mathrm{~m}$ & $\begin{array}{l}\text { Sapwood } \\
\text { Wetwood edge } \\
\text { Central wetwood }\end{array}$ & $\begin{array}{l}4.1 \times 10^{3} \\
9.4 \times 10^{5} \\
1.0 \times 10^{6}\end{array}$ & $\begin{array}{l}<10^{2} \\
<10^{2} \\
<10^{2}\end{array}$ \\
\hline 118 & $8.5 \mathrm{~m}$ & $\begin{array}{l}\text { Sapwood } \\
\text { Wetwood edge } \\
\text { Central wetwood } \\
\text { Sapwood } \\
\text { Wetwood edge } \\
\text { Central wetwood }\end{array}$ & $\begin{array}{l}9.3 \times 10^{3} \\
2.5 \times 10^{5} \\
2.0 \times 10^{7} \\
4.0 \times 10^{5} \\
1.1 \times 10^{6} \\
1.9 \times 10^{7}\end{array}$ & $\begin{array}{l}6.4 \times 10^{2} \\
5.0 \times 10^{2} \\
9.7 \times 10^{3} \\
1.8 \times 10^{3} \\
6.5 \times 10^{5} \\
5.0 \times 10^{3}\end{array}$ \\
\hline
\end{tabular}

aerobic isolates from wetwood were assigned to the genus Pseudomonas. One of these produced a yellow pigment.

Both types of bacteria isolated from the anaerobic dilution series from wetwood were facultative anaerobes, which were assigned to the genera Klebsiella and Vibrio. The Klebsiella strains formed acetate, ethanol, and hydrogen as fermentation products, the Vibrio strains ethanol, acetate, and acetoin. The latter produced large amounts of slime when grown on a glucose medium.

The predominant aerobic isolates from sapwood

Table 3

Prevalent microorganisms from fir wood samples

\begin{tabular}{lllllll}
\hline Strain & Shape & $\begin{array}{l}\text { Gram } \\
\text { reaction }\end{array}$ & $\begin{array}{l}\text { Oxygen } \\
\text { dependence }\end{array}$ & Special properties & Assigned to genus & $\begin{array}{l}\text { Isolated } \\
\text { from }\end{array}$ \\
\hline Ta ae 3 & Coccus & + & Aerobic & Yeast & - & Wetwood \\
Ta ae 11 & Rod & - & Aerobic & Pink colonies & Protaminobacter & Wetwood \\
Ta ae 8 & Rod & - & Aerobic & Yellow pigment & Pseudomonas & Wetwood \\
Ta ae 13 & Rod & - & Aerobic & - & Pseudomonas & Wetwood \\
Ta an 14 & Rod & - & Facultative & - & Klebsiella & Wetwood \\
Ta an 6 & Rod & - & Facultative & Slime & Vibrio & Wetwood \\
Ta ae 1 & Rod & + & Aerobic & Spores, slime & Bacillus & Sapwood \\
Ta ae 24 & Rod & - & Aerobic & Pink colonies & Beijerinckia? & Sapwood \\
Ta ae 27 & Coccus & + & Facultative & - & Staphylococcus & Sapwood \\
Ta an 2 & Rod & + & Anaerobic & Spores & Clostridium & Sapwood \\
\hline
\end{tabular}


samples were grouped with the genera Bacillus, Beijerinckia, and Staphylococcus. In anaerobic counts, a Clostridium strain predominanted which formed acetate and propionate as fermentation products.

None of the isolated strains was able to grow with cellulose or arabinogalactan as substrates. Xylan was used by only 2 anaerobic isolates, and pectin only by the Clostridium strain isolated from sapwood (Table 4). Glucose and cellobiose supported growth of most isolates, and xylose and arabinose were used by only a few strains. One of the Pseudomonas strains predominating in wetwood (Taae13) did not degrade any sugars and grew only with lactate or amino acids.

\subsection{Characterization of microbial populations in a} diseased vine (Vitis vinifera $L$.)

A diseased vine plant was used for a comparative study on microbial populations in wood tissues. The leaves had started to wither, the primary root ring had died off and a secondary root ring had formed above it. Samples were taken in the center of the root stock at 3 sites in and above the secondary root ring.

The numbers of aerobic microorganisms varied between $4 \times 10^{6}$ and $3 \times 10^{8}$ per $\mathrm{g}$ fresh wood; those of anaerobes between $6 \times 10^{4}$ and $3 \times 10^{6}$. These numbers indicate a high degree of microbial colonization of this living root tissue. The predominant strains in aerobic counts were assigned to the genera Klebsiella, Protaminobacter, Microcyclus, Bacillus, and Erwinia. Also, yeasts similar to strain Taae 3 and a fungus were found at the lowest sampling site. In anaerobic counts, Aeromonas, Clostridium, and Klebsiella strains predominated.

\section{DISCUSSION}

\subsection{Development of methods for recovery of micro- organisms}

The well-known difficulties of quantitating microbial populations in natural samples are due to a variety of circumstances. (i) Any enumeration method based on cultivation techniques, e.g., plate counting, is highly selective and can apply only to a small fraction, usually not more than $5-10 \%$ of the total population present. (ii) Direct counting techniques, even if aided by fluorescent dye treatment, do not differentiate between living and dead cells, and do not allow any conclusions on the physiological properties of the organisms in view. (iii) Microorganisms often tend to adsorb to particles of any kind, and reliable enumeration requires the resolution of cells from particle surfaces and from each other. Considering microbial populations in wood samples, a further problem arises from the highly organized, rigid texture of the wood tissue which makes the problem of quantitative resolution extremely difficult.

Table 4

Utilization of selected substrates by isolates from fir wood samples

No isolate used cellulose or arabinogalactan; n.d., not determined.

\begin{tabular}{|c|c|c|c|c|c|c|c|c|c|}
\hline Genus & Strain & Cellobiose & Glucose & Xylan & Xylose & Arabinose & Pectin & Lactate & Yeast extract \\
\hline (Yeast) & Ta ae 3 & + & + & - & + & n.d. & - & - & \pm \\
\hline Protaminobacter & Ta ae 11 & - & + & - & - & - & - & + & \pm \\
\hline Pseudomonas & Ta ae 8 & + & + & - & + & + & - & - & + \\
\hline Pseudomonas & Ta ae 13 & - & - & - & - & - & - & + & + \\
\hline Klebsiella & Ta an 14 & + & + & + & + & + & - & - & - \\
\hline Vibrio & Ta an 6 & \pm & + & - & - & - & - & - & \pm \\
\hline Bacillus & Ta ae 1 & \pm & + & - & - & \pm & - & + & - \\
\hline Beijerinckia & Ta ae 24 & + & \pm & - & + & - & - & \pm & + \\
\hline Staphylococcus & Ta ae 27 & - & \pm & - & - & - & - & + & + \\
\hline Clostridium & Ta an 2 & + & + & \pm & + & - & + & \pm & - \\
\hline
\end{tabular}


On the other hand, only quantitative studies of microbial populations and concentration on the numerically prevalent microbes allow reliable conclusions on metabolic activities in a natural environment. This approach also helps to circumvent the pitfall of dealing with fast-growing and easyto-cultivate microbes which might be irrelevant to the environment studied, or might even be contaminants introduced during sample processing. Therefore, the numerous reports on casual isolations of bacteria from various kinds of wetwood are of only limited value if one wants to characterize wetwood as a microbial habitat.

First quantitative studies on microbial populations in wetwood have been carried out with Eastern cottonwood (Populus deltoides Bartr.) and American elm (Ulmus americana L.) [24]. The authors homogenized wood cores in reduced anoxic growth media in a Waring blender inside an anaerobic hood, and found up to $10^{8}$ cells of heterotrophic anaerobes per $g$ of wood tissue. This procedure might be detrimental for aerobic bacteria, which were always found in lower numbers. For enumeration, a comparatively rich medium was used, which might be very different from conditions in wood tissue.

It was the goal of the present study to develop a method allowing the reliable recovery of aerobic and anaerobic bacteria from wood extracts. The method also had to be suitable for use in laboratories without anaerobic hoods. For this reason, the blender was placed in a cylindrical vessel which could be opened from the top and gassed continuously with carbon dioxide. This simple device can be set up easily in any laboratory. Ascorbate turned out to give sufficient protection against traces of oxygen to fermenting and sulfate-reducing bacteria, whereas other reducing agents were less effective. In the absence of reducing agents, Desulfovibrio sp. survived oxygen stress very well, showing again that oxygen toxicity is often caused by reaction products of oxygen and reducing agents [25].

Potassium phosphate buffer, $\mathrm{pH} 7.0$, was optimal for the extraction of bacteria from wood homogenate at low molarity $(5 \mathrm{mM})$. Additions of tensides, which were advantageous for the resolution of bacteria from sediment particles [26], did not enhance the recovery, nor did complexing or chaotropic agents improve the results. This may indicate that the bacteria in the wood tissue are not adsorbed to surfaces by hydrophobic interaction or cationic bridges. Variation in the buffer system or the $\mathrm{pH}$ also gave lower viable counts. Physical support of resolution by sonication, which was helpful in resolving activated sludge bacteria [27] was equally useless. Repeated evacuation and gassing was reported to be an optimal method for the recovery of microorganisms from spruce wood blocks [12]. This procedure was also without effect in our hands, probably because the wood tissue was largely destroyed during the blending process.

Direct counting after fluorescence staining with acridine orange or 4,6-diamidino-2-phenylindole was attempted with wood extracts obtained with the methods described above. Unfortunately, the wood particles of various sizes were stained as well, and gave a high background fluorescence which rendered counting of the bacterial cells practically impossible. We therefore counted aerobic and anaerobic bacteria separately in plate dilution and agar shake dilution series to ensure reliable aerobic and anaerobic conditions in each case. This method also allowed isolation and characterization of the prevalent strains in every case, and thus gave some insight into the conditions prevailing in the wetwood studied. Nonetheless, it should be made clear that by this method only a small fraction of the microbial population was taken into account: direct fluorescence counts, if at all possible, gave about 10-20 times higher numbers than those obtained in dilution series. This is about the same ratio of culturable to total microbial counts that is found in other natural samples (see above).

\subsection{Microbial populations in fir wetwood}

Sapwood samples of fir stems contained low numbers of aerobic and anaerobic bacteria, about $10^{3}-10^{4}$ cells per $g$ wood tissue. The numbers were significantly lower in the less afflicted tree, No. 119, at a height of $15 \mathrm{~m}$, far above the wetwood zone. Numbers of aerobic bacteria usually exceeded those of anaerobic ones, indicating that this environment can be considered as aerobic or at least microaerobic. Wetwood of this same 
tree contained similar, sometimes even lower numbers of bacteria than sapwood, and again anaerobes were less prevalent than aerobes.

Only wetwood of the highly afflicted trees Nos. 107 and 118 was characterized by high numbers of culturable microorganisms $\left(10^{5}-10^{7}\right.$ cells per g), and the counts increased within the wetwood zone from the periphery to the center. The number of anaerobic bacteria was not increased. Among the prevailing aerobic isolates were Protaminobacter and Pseudomonas strains as well as a yeast, whereas facultative anaerobes of the genera Klebsiella and Vibrio predominated in anaerobic dilution series. These results were surprising. Firstly, we expected the bacterial populations to be maximal at the wetwood periphery where nutrients should be available, and to decline towards the center due to nutrient depletion. Secondly, the presence of fermentation products typical of strict anaerobes (acetate, propionate, and butyrate) [16] suggested that strict anaerobes should occur in this wetwood type. Both findings can be explained assuming that wetwood in firs develops very fast as a consequence of a physiological disorder, e.g., due to environmental stress. This assumption agrees with the early observation that wetwood occurs in firs only under stress conditions [28], no matter whether these are due to chemical or microbial influences [29-34]. Nutrients left in the heartwood together with sufficient oxygen supply through the wide-meshed wood structure supports a huge population of aerobic bacteria. Their activity may establish anoxic microniches in which numerically less abundant strict anaerobes perform the fermentation processes which produce the products mentioned above. It is evident that fastidious methanogenic communities cannot become established under these conditions, and that fermentations stop at the acidogenic stage rendering an acidic environment. Such a system can only be maintained for short times at the expense of high nutrient supply, and this may explain why wetwood in firs and other conifers is a pathological symptom leading to a fast decline of the affected tree. In contrast, microbial communities in the well-stabilized neutral to slightly alkaline wetwoods of cottonwoods, poplars and elms degrade wood constituents complete to methane and carbon dioxide, and can remain established for decades without killing their host tree [1]. Whether this difference is due to a better nutrient supply, impeded oxygen diffusion, or the absence of, e.g., phenolic wood extractives toxic to methanogenic bacteria is still a matter of speculation [8].

The prevailing microorganisms found in wetwood of highly diseased firs grew only with monomeric sugars; only one strain could grow with xylan. In wetwoods of cottonwoods and elms, degradation of pectin was demonstrated, which destroyed pit membranes and thus exposed a rich variety of substrates to the microbial community [24,35]. Recently, also anaerobic cellulose degradation in wetwoods of elm and maple was reported, however, only on the basis of casual isolations of bacteria [36]. The finding that microbial populations in fir wetwood do not significantly attack the major wood constituents may be another reason for the fast spreading of this kind of wetwood in the stem, which appears to be a typical pathological symptom of the afflicted firs, and might be a significant factor in fir dieback.

\section{ACKNOWLEDGEMENT}

The authors are indebted to Prof. Dr. Norbert Pfennig for valuable discussions and support, as well as to Prof. Dr. Josef Bauch for providing trees for sampling and contributing to the content of this paper by fruitful discussions. Prof. Dr. Kurt Mendgen is thanked for providing a withered vine plant for our studies.

\section{REFERENCES}

[1] Hartley, C., Davidson, R.W. and Crandall, B.S. (1961) Wetwood, bacteria and increased $\mathrm{pH}$ in trees, U.S. Dept. Agric. For. Service, For. Prod. Lab. Rep. 2215, 35.

[2] Hillis, W.E. (1977) Secondary changes in wood, in Recent Advances in Phytochemistry 11 (Loewus, F.A. and Runeckles, V.C., Eds.) pp. 247-309. Plenum Press, New York.

[3] Carter, J.C. (1945) Wetwood of elms, Natural History Survey Division, Urbana, IL Bull. 23, 407-448.

[4] Murdoch. C.W., Biermann, C.J. and Campana, R.J. (1983) Pressure and composition of intrastem gases produced in wetwood of American elm. Plant Dis. 67, 74-76. 
[5] Zeikus, J.G. and Ward, J.C. (1974) Methane formation in living trees: a microbial origin, Science 184, 1181-1183.

[6] Morani, V. and Arru, G.M. (1958) Accumulo di gas entro pioppi in vegetazione, Ric. Sci. 28, 146-151.

[7] Scott, E.S. (1984) Populations of bacteria in poplar stems. Eur. J. For. Pathol. 14, 103-112.

[8] Schink, B. and Ward, J.C. (1984) Microaerobic and anaerobic bacterial activities involved in formation of wetwood and discoloured wood, IAWA Bull. 5, 105-109.

[9] Ward, J.C. and Zeikus, J.G. (1980) Bacteriological, chemical and physical properties of wetwood in living trees, in Natural Variations of Wood Properties Mitt. Bundesforschungsanstalt f. Forst- und Holzwirtschaft (Bauch, J., Ed.) Vol. 131, pp. 133-166. Wiedebusch, Hamburg.

[10] Worrall, J.J. and Parmeter, J.R. (1982) Formation and properties of wetwood in white fir, Phytopathology 72 , 1209-1212.

[11] Ward, J.C. and Pong, W.Y. (1980) Wetwood in trees: a timber resource problem, in USDA Forest Service Gen. Tech. Rep. PNW, pp. 56-112 Pacific Northwest Forest and Range Exp. Station, Portland, OR.

[12] Schmidt, O. (1985) Occurrence of microorganisms in the wood of Norway spruce trees from polluted sites, Eur. J. For. Pathol. 15, 2-10.

[13] Schmidt, O. and Kebernik, U. (1984) Characterization of microorganisms from spruce trees from polluted sites, Mater. Org. 19, 81-93.

[14] Bauch, J., Höll, W. and Endeward, R. (1975) Some aspects of wetwood formation in fir, Holzforschung 29, 198-205.

[15] Bauch, J., Klein, P., Frühwald, A. and Brill, H. (1979) Alterations of wood characteristics in Abies alba Mill. due to 'fir-dying' and considerations concerning its origin. Eur. J. For. Pathol. 9, 321-331.

[16] Brill, H., Bock, E. and Bauch, J. (1981) Über die Bedeutung von Mikroorganismen im Holz von Abies alba Mill. für das Tannensterben, Forstwissensch. Centralbl. 100 , 195-206.

[17] Widdel, F. and Pfennig, N. (1981) Studies on dissimilatory sulfate-reducing bacteria that decompose fatty acids, I. Isolation of new sulfate-reducing bacteria enriched with acetate from saline environments. Description of Desulfobacter postgatei gen. nov., sp. nov., Arch. Microbiol. $129,395-400$.

[18] Schink, B. and Pfennig, N. (1982) Fermentation of trihydroxybenzenes by Pelobacter acidigallici gen. nov. sp. nov., a new strictly anaerobic, non-sporeforming bacterium, Arch. Microbiol. 133, 195-201.

[19] Widdel, F., Kohring, G.-W. and Mayer, F. (1983) Studies on dissimilatory sulfate-reducing bacteria that decompose fatty acids, III. Characterization of the filamentous gliding Desulfonema limicola gen. nov. sp. nov., and Desulfonema magnum sp. nov., Arch. Microbiol. 134, 286-294.

[20] Pfennig, N. (1978) Rhodocyclus purpureus gen. nov. and sp. nov., a ring-shaped, vitamin $B_{12}$-requiring member of the family Rhodospirillaceae, Int. J. Syst. Bacteriol. 28 , $283-288$
[21] Magee, C.M., Rodeheaver, G., Edgerton, M.T. and Edlich, R.F. (1975) A more reliable Gram staining technic for diagnosis of surgical infections, Am. J. Surg. 130, 341-346.

[22] Hugh, R. and Leifson, E. (1953) The taxonomic significance of fermentative versus oxidative metabolism of carbohydrates by various gram-negative bacteria, J. Bacteriol. 66, 24-26.

[23] Sato, K. (1978) Bacteriochlorophyll formation by facultative methylotrophs, Protaminobacter ruber and Pseudomonas AMI, FEBS Lett. 85, 207-210.

[24] Schink, B., Ward, J.C. and Zeikus, J.G. (1981) Microbiology of wetwood: role of anaerobic bacterial populations in living trees, J. Gen. Microbiol. 123, 313-322.

[25] Cypionka, H., Widdel, F. and Pfennig, N. (1985) Survival of sulfate-reducing bacteria after oxygen stress, and growth in sulfate-free oxygen-sulfide gradients, FEMS Microbiol. Ecol. 31, 39-45.

[26] Scheraga, M., Meskill, M. and Litchfield, C.D. (1979) Analysis of methods for the quantitative recovery of bacteria sorbed onto marine sediments, in Methodology of Biomass Determinations and Microbial Activities in sediments, ASTM STP 673 (Litchfield, C.D., Seyfried, P.L., Eds.) pp. 21-39. Am. Soc. for Testing and Materials, Washington, DC.

[27] Banks, C.J. and Walker, J. (1977) Sonication of activated sludge flocs and the recovery of their bacteria on solid media, J. Gen. Microbiol. 98, 369-377.

[28] Neger, F.W. (1908) Das Tannensterben in den sächsischen und anderen deutschen Mittelgebirgen, Thar. Forstl. Jahrb. $58,201-225$.

[29] Fink, S. and Braun, H.J. (1978) Zur epidemischen Erkrankung der Weisstanne Abies alba Mill., I. Untersuchungen zur Symptomatik und Formulierung einer Virose-Hypothese, Allg. Forst-Jagdztg. 149, 145-150.

[30] Schütt, P. (1981) Ursache und Ablauf des Tannensterbens -Versuche einer Zwischenbilanz, Forstwissensch. Centralbl. 100, 286-287.

[31] Bauch, J. (1983) Biological alterations in the stem and root of fir and spruce due to pollution influence, in Effects of Accumulation of Air Pollutants in Forest Ecosystems (Ulrich, B. and Pankrath, J., Eds.) pp. 377-386. D. Reidel, Dordrecht.

[32] Zech, W. and Popp, E. (1983) Magnesiummangel, einer der Gründe für das Fichten- und Tannensterben in NOBayern, Forstwissensch. Centralbl. 102, 50-55.

[33] Kandler, O. (1983) Waldsterben: Emissions- oder Epidemiehypothese? Naturwiss. Rundsch. 36, 488-490.

[34] Lichtenthaler, H.K. (1984) Luftschadstoffe als Auslöser des Baumsterbens, Naturwiss. Rundsch. 37, 271-277.

[35] Schink, B., Ward, J.C. and Zeikus, J.G. (1981) Microbiology of wetwood: Importance of pectin degradation and Clostridium species in living trees, Appl. Environ. Microbiol. 42, 526-532.

[36] Warshaw, J.E., Leschine, S.B. and Canale-Parola, E. (1985) Anaerobic cellulolytic bacteria from wetwood of living trees, Appl. Environ. Microbiol. 50, 807-811. 